\title{
Undercurrents of Power
}




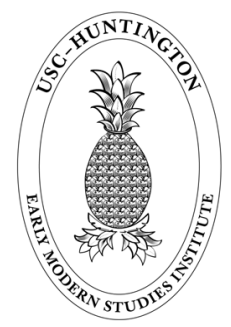

THE EARLY MODERN AMERICAS

Peter C. Mancall, Series Editor

Volumes in the series explore neglected aspects of early modern history in the western hemisphere. Interdisciplinary in character, and with a special emphasis on the Atlantic World from 1450 to 1850 , the series is published in partnership with the USC-Huntington Early Modern Studies Institute. 


\section{Undercurrents of Power}

Aquatic Culture in the African Diaspora

\section{Kevin Dawson}

\section{$\overline{\text { PENN }}$}

UNIVERSITY OF PENNSYLVANIA PRESS

PHILA DELPHIA 
Copyright (C) 2018 University of Pennsylvania Press

All rights reserved. Except for brief quotations used for purposes of review or scholarly citation, none of this book may be reproduced in any form by any means without written permission from the publisher.

Published by

University of Pennsylvania Press

Philadelphia, Pennsylvania 19104-4112

www.upenn.edu/pennpress

Printed in the United States of America

on acid-free paper

$\begin{array}{llllllllll}10 & 9 & 8 & 7 & 6 & 5 & 4 & 3 & 2 & 1\end{array}$

Library of Congress Cataloging-in-Publication Data

Names: Dawson, Kevin (Historian), author.

Title: Undercurrents of power: aquatic culture in the African diaspora /

Kevin Dawson.

Other titles: Early modern Americas.

Description: 1st edition. | Philadelphia: University of Pennsylvania Press, [2018] | Series: The early modern Americas | Includes bibliographical references and index.

Identifiers: LCCN 2017032704 | ISBN 9780812249897 (hardcover: alk. paper)

Subjects: LCSH: African diaspora—History. | Africans-America-Ethnic identity—History. | Slaves-America—Social conditions. | Aquatic sports—Africa-History. | Aquatic sports-America-History. | Boats and boating-Africa-History. | Boats and boating-America-History.

Classification: LCC DT16.5 .D39 2018 | DDC 305.896/070903-dc23

LC record available at https://lccn.loc.gov/2017032704 
To the waters of the Atlantic world and those enslaved Africans who suffered and endured so their story might be told 
